\title{
Front Matter: Volume 11648
}

, "Front Matter: Volume 11648," Proc. SPIE 11648, Multiphoton Microscopy in the Biomedical Sciences XXI, 1164801 (16 April 2021); doi:

$10.1117 / 12.2596570$

SPIE. Event: SPIE BiOS, 2021, Online Only 


\title{
PROGRESS IN BIOMEDICAL OPTICS AND IMAGING

\section{Multiphoton Microscopy in the Biomedical Sciences XXI}

\author{
Ammasi Periasamy \\ Peter T. So \\ Karsten König \\ Editors
}

\author{
6-11 March 2021 \\ Online Only, United States
}

\section{Sponsored by \\ SPIE}

\section{Cosponsored by}

Thorlabs (United States) • Leica Microsystems (United States) - Becker \& Hickl GmbH (Germany) Spectra-Physics (United States) - Carl Zeiss (United States) - Applied Scientific Instrumentation (United States) - Chroma Technology Corporation (United States) - PicoQuant Photonics (United States) • Coherent Inc. (United States) • Semrock Inc. (United States) • Excelitas Technologies ISS, Inc. (United States) • LaVision BioTec GmbH (Germany)

Published by

SPIE

\section{Volume 11648}


The papers in this volume were part of the technical conference cited on the cover and title page. Papers were selected and subject to review by the editors and conference program committee. Some conference presentations may not be available for publication. Additional papers and presentation recordings may be available online in the SPIE Digital Library at SPIEDigitalLibrary.org.

The papers reflect the work and thoughts of the authors and are published herein as submitted. The publisher is not responsible for the validity of the information or for any outcomes resulting from reliance thereon.

Please use the following format to cite material from these proceedings:

Author(s), "Title of Paper," in Multiphoton Microscopy in the Biomedical Sciences XXI, edited by Ammasi Periasamy, Peter T. So, Karsten König, Proceedings of SPIE Vol. 11648 (SPIE, Bellingham, WA, 2021) Seven-digit Article CID Number.

ISSN: 1605-7422

ISSN: 2410-9045 (electronic)

ISBN: 9781510641310

ISBN: 9781510641327 (electronic)

Published by

SPIE

P.O. Box 10, Bellingham, Washington 98227-0010 USA

Telephone +1 3606763290 (Pacific Time) · Fax +1 3606471445

SPIE.org

Copyright (c) 2021, Society of Photo-Optical Instrumentation Engineers.

Copying of material in this book for internal or personal use, or for the internal or personal use of specific clients, beyond the fair use provisions granted by the U.S. Copyright Law is authorized by SPIE subject to payment of copying fees. The Transactional Reporting Service base fee for this volume is $\$ 21.00$ per article (or portion thereof), which should be paid directly to the Copyright Clearance Center (CCC), 222 Rosewood Drive, Danvers, MA 01923 . Payment may also be made electronically through CCC Online at copyright.com. Other copying for republication, resale, advertising or promotion, or any form of systematic or multiple reproduction of any material in this book is prohibited except with permission in writing from the publisher. The CCC fee code is 1605$7422 / 21 / \$ 21.00$.

Printed in the United States of America by Curran Associates, Inc., under license from SPIE.

Publication of record for individual papers is online in the SPIE Digital Library.

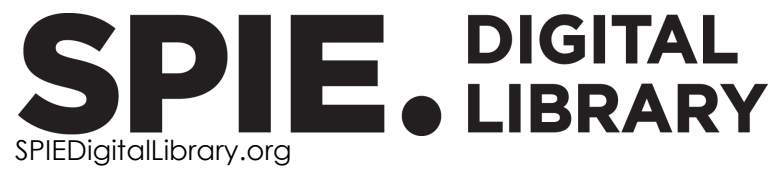

Paper Numbering: Proceedings of SPIE follow an e-First publication model. A unique citation identifier (CID) number is assigned to each article at the time of publication. Utilization of CIDs allows articles to be fully citable as soon as they are published online, and connects the same identifier to all online and print versions of the publication. SPIE uses a seven-digit CID article numbering system structured as follows:

- The first five digits correspond to the SPIE volume number.

- The last two digits indicate publication order within the volume using a Base 36 numbering system employing both numerals and letters. These two-number sets start with 00, 01, 02, 03, 04, $05,06,07,08,09,0 A, 0 B \ldots$ OZ, followed by 10-1Z, 20-2Z, etc. The CID Number appears on each page of the manuscript. 


\section{Contents}

V Introduction

FLIM/FRET/FCS I

11648 OA Skin cancer detection with a compact multimodal fiber laser multiphoton FLIM tomograph (Invited Paper) [1 1648-5]

11648 OB Multiplexing FRET by PIE-FastFLIM and the phasor plots (Invited Paper) [1 1648-6]

11648 OC Quantitation of cerebral oxygen tension using phasor analysis and phosphorescent lifetime imaging microscopy (PLIM) (Invited Paper) [1 1648-7]

\section{FLIM/FRET/FCS II}

$11648 \mathrm{OE} \quad$ An overview of continuous and discrete phasor analysis of binned or time-gated periodic decays [1 1648-9]

METABOLISM-NADH/FAD/TRYPTOPHAN

11648 OL Discrimination of urinary tract infection bacteria using redox imaging (Invited Paper) [1 1648-20]

$1164800 \quad$ Multiphoton confocal imaging of mammalian cells in presence of Zinc Nitride nanoparticle [1 1648-23]

TECHNOLOGY AND APPLICATIONS I

11648 OP Microfluid setup for high throughput laser-assisted cell transfection (Invited Paper) [11648-29]

SHG/THG MICROSCOPY I

11648 OX Intratumoral heterogeneity of second-harmonic generation scattering from tumor collagen and its effects on metastatic risk prediction [1 1648-25] 
1164811 Flexible and compact multiphoton microscope with fiber delivered femtosecond-NIR laser pulses [11648-36]

1164813 The transition dipole moment representation and spectral phasors [11648-38]

1164814 Modelling and comparison of image-analysis algorithms to measure blood velocity with laser scanning microscopy [11648-39]

\section{IN VIVO IMAGING}

1164817 Simultaneous multimodal optical coherence and three-photon microscopy of the mouse brain in the $1700 \mathrm{~nm}$ optical window in vivo (Invited Paper) [1 1648-13]

1164818 Fast in vivo multiphoton microscopy using optimized light-sheet illumination (Invited Paper) [11648-14]

1164819 High power OPCPA system for in-vivo 2- and 3-photon brain imaging [1 1648-15]

$116481 \mathrm{~A}$ Theoretical and experimental investigation of the depth limit of three-photon microscopy [11648-16]

\section{POSTER SESSION}

$116481 \mathrm{C}$ Convolutional neural network denoising in fluorescence lifetime imaging microscopy (FLIM) [11648-43]

11648 1D Image processing routine to analyze mitochondrial membrane potential in single cells with TMRE [11648-44]

$11648 \mathrm{IE} \quad$ Labeling enhancement of hydrophilic and hydrophobic molecules in tissue sections [1 1648-45]

$11648 \mathrm{IF}$ Microscopic imaging of the effects of formaldehyde fixation on tissue autofluorescence [11648-46]

11648 1G Machine learning architecture to predict drug response based on cancer cell FLIM images [11648-47]

$11648 \mathrm{lH} \quad$ Novel pH-responsive highly fluorescent lipophilic coumarins as efficient two-photon sensors of acidic and basic environments [1 1648-48]

$116481 \mathrm{~K} \quad$ Metabolic imaging and secondary ion mass spectrometry analysis to investigate liver structure and function during regeneration [11648-51] 


\section{Introduction}

Thirty-one years have passed since the realization of two-photon laser scanning microscopy. This conference has been running for the last 21 years. Due to the COVID19 pandemic, the conference become a Digital Forum.

Briefly, considering the historical perspective of multiphoton microscopy, in 1931, Maria Göppert-Mayer reported the quantum mechanical formulation of two-photon molecular excitation in her doctoral thesis'. Two-photon excited fluorescence was finally demonstrated by Kaiser and Garrett2 shortly after the invention of the laser in 1960. Sheppard and co-workers developed the SHG microscope 3 for solid state specimens and Denk, Strickler, and Webb developed a non-linear fluorescence microscope and first showed that it can be applied to image biological system noninvasively 4 . Since then, the usage and the development of multiphoton microscopy has increased tremendously. More importantly, the commercialization of multiphoton imaging systems by Bio-Rad did increase awareness and application of this technology in biomedical imaging. It should also be recognized that laser companies (Spectra Physics and Coherent) played a key role in introducing tunable (700-1100 nm; currently from 680 to $1300 \mathrm{~nm}$ ) femtosecond infrared-pulsed laser systems (Ti: sapphire) for multiphoton imaging. Moreover, the future will bring even easier-to-use equipment and increased sensitivity, which will allow greater flexibility in the simultaneous imaging of multiple fluorophores while images are collected over time and at greater depths inside tissue/live animals 5 .

Multiphoton microscopy has been established as the 3-D imaging method of choice for studying living biomedical specimens from single cells and whole animals to patients with sub-micron resolution. The ever-expanding scope of applications and the continuing instrumental innovations require a forum where new ideas can be exchanged and presented. Our conference at the SPIE BIOS2021 Digital Forum continues to address this need.

This is the $21^{\text {st }}$ year of this conference and we start with Keynote lectures from leaders in various fields in multiphoton microscopy development and applications. More importantly, we had invited speakers from around the world share their ideas and achievements using this novel technology.

(1) Alfred Vogel (Germany). Leaving any number of photons behind: Adventures in structural neurobiology

(2) Melissa Skala, University Wisconsin at Madison (United States), Evolution of multiphoton microscopy over three decades: Current perspectives and future directions 
Due to the pandemic, we did not award the JenLab Young Investigators award and poster award.

On the exciting note, we had a great Networking Session via Zoom held on March $7^{\text {th }}$. The title of the Network session was "New Trends in Multiphoton Microscopy". Thanks to Ms. Dawn Jackson, SPIE, for arranging the Network session. Many investigators around the world participated in the Network session and gave an exciting talk in that session. About 67 participants from around the world participated in the Network session. This Network session was Chaired by the Conference Chair, Prof. Ammasi Periasamy, University of Virginia. Here is the list of Investigators who presented their interesting work.

1. Prof. Peter So, MIT, Boston (USA)- De-scattering with Excitation Patterning (DEEP) Enables Rapid Wide-field Imaging Through Scattering Media

2. Prof. Ji-Xin Cheng, Boston University, Boston (USA) - multiphoton microscopy using two laser beams

3. Prof. Michelle A. Digman, University of California at Irvine (USA) - 2p hyperspectral Imaging

4. Prof. Fu-Jen Kao, National Yang Ming University, Taipei (Taiwan) Quantitative Pump-Probe Microscopy with Stimulated Emission

5. Prof. Junle QU, ShenZhen University (China) - nonlinear optical imaging for photobiomodulation of brain disease

6. Dr. Angelika Rueck, Ulm University (Germany) - New Trends in 2p Metabolic FLIM

7. Dr. Marina Shirmanova, Privolzhsky Research Medical University, Nizhny Novgorod (Russia) - Combination of metabolic imaging and genetically encoded sensors for cancer research

8. Prof. Chris XU, Cornell University, New York (USA) - The possibility of resonance-enhanced multiphoton excitation.

9. Prof. Conor Evans, Harvard Medical School, Boston (USA) Multiphoton Chemical Imaging to Assess Dermal Pharmacokinetics and Pharmacodynamics.

10. Prof. Karsten Koenig, Saarland University, Saarbruecken and CEO of JenLab (Germany) - Novel multimodal multiphoton tomograph based on an ultracompact femtosecond fiber laser.

Some of the most valuable contributions in this volume are articles written by highly experienced practitioners of multiphoton microscopy. They have enumerated the most important considerations in designing multiphoton microscopes and imaging experiments. Further, updates on the state-of-the-art commercial multiphoton microscope systems are presented. This volume also includes articles describing some recent advances in major multiphoton microscope components and applications including laser light sources, ultra-fast optics, filters, FRET, FLIM, FCS, Raman, CARS, SRS and Coherent Raman microscopy and spectroscopy, single molecule, endoscopy, In Vivo/Intravital imaging, metabolism measurements 
including NADH, FAD, tryptophan in cells and tissues and various scientific and clinical applications.

On a personal note, the conference chairs are grateful for the participation of all authors, session chairs and acknowledge the innovation-driven manufacturers and sponsors of this conference [Applied Scientific Instruments (ASI), Becker \& Hickl, Carl Zeiss, Chroma Technology, Coherent, ISS Inc., Excelitas Technologies, JenLab, LaVision BioTec, Leica Microsystems, PicoQuant, Semrock (IDEX), Spectra Physics \& Newport (mks company)] and Thorlabs for their enthusiastic support in organizing this conference. We look forward to other exciting conferences in the future and welcome your continued participation and support.

Note: Late Prof. Watt Webb, Cornell University, New York, passed away in October 2020 (1927-2020). He is the inventor of multiphoton micrsocopy for biological sciences. Prof. Webb is the pioneer in methods for imaging living biological systems. He gave a Keynote lecture in the opening ceremony of the Multiphoton Microoscpy in the Biomedical Sciences in 2001 and later in 2009. We plan to have a one day speical session to celelbrate his achievements during Janaury 22-27, 2022 at the Photonics West meeting, Moscone Convention Center, San Franicsio.

1. M. Göppert-Mayer, "Über elementarakte mit zwei quantensprüngen," Ann. Phys. $401(3)$, 273-294 (1931).

2. W. Kaiser and C. Garrett, "Two-photon excitation in CaF2:Eu2p," Phys. Rev. Lett. $7(6)$, 229-231 (1961).

3. J. Gannaway and C. Sheppard, "Second-harmonic imaging in the scanning optical microscope," Opt. Quantum Electron. 10(5), 435-439 (1978).

4. W. Denk, J. H. Strickler, and W. W. Webb, "Two-photon laser scanning fluorescence

microscopy," Science 248(4951), 73-76 (1990).

5. A. Periasamy, K. König, and So, P., Special Section Guest Editorial: Thirty Years of Multiphoton Microscopy in the Biomedical Sciences. J. Biomed. Opt. 25(1), 014501 (2020), doi: 10.1117/1.JBO.25.1.014501

\section{Ammasi Periasamy \\ Peter T. So Karsten König}


Proc. of SPIE Vol. 11648 1164801-8 Downloaded From: https://www.spiedigitallibrary.org/conference-proceedings-of-spie on 25 Apr 2023
Terms of Use: https://www.spiedigitallibrary.org/terms-of-use 